\title{
Termitomenins F and G, Two New Lignan Glucosides from Terminalia chebula var. tomentella (Kurz) C. B. Clarke
}

\author{
Jun Yin ${ }^{1,2} \cdot$ Hong-Tao Zhu ${ }^{1} \cdot$ Man Zhang ${ }^{1} \cdot$ Dong Wang ${ }^{1} \cdot$ Chong-Ren Yang ${ }^{1} \cdot$ Ying-Jun Zhang $^{1,3}$ (1)
}

Received: 30 April 2021 / Accepted: 24 May 2021 / Published online: 10 June 2021

(c) The Author(s) 2021

\section{Abstract}

The extensive chemical investigation on the branches and leaves of Terminalia chebula var. tomentella (Combretaceae) led to the isolation of two new lignan glucosides with a furofuran skeleton, termitomenins F (1) and G (2). In addition, 19 known compounds including five lignan glucosides (3-7), six hydrolyzable tannins (8-13) and eight simple phenolics (14-21) were also identified. Their structures were determined by comprehensive spectroscopic analyses. It is noted that $\mathbf{8}$ and $\mathbf{9}$ were $C$-glycosidic hydrolyzable tannins with one hexahydroxydiphenoyl and one gallagyl group linked to an open-chain glucosyl $C-1 / O-2 / O-3$ and $O-4 / O-6$, respectively, which were rarely found in plants. Nine known compounds, 6-9, 13, and 18-21, were procured from the titled plant for the first time, while 3-5, 10-12 and 14-17 were also found in the fruits. Notably, the known hydrolyzable tannins $\mathbf{8}-\mathbf{1 3}$ exhibited stronger $\alpha$-glucosidase inhibitory activities with $\mathrm{IC}_{50}$ values ranging from 0.10 to $3.12 \mu \mathrm{M}$, than the positive control, quercetin $\left(\mathrm{IC}_{50}=9.38 \pm 0.33 \mu \mathrm{M}\right)$.

\section{Graphic abstract}

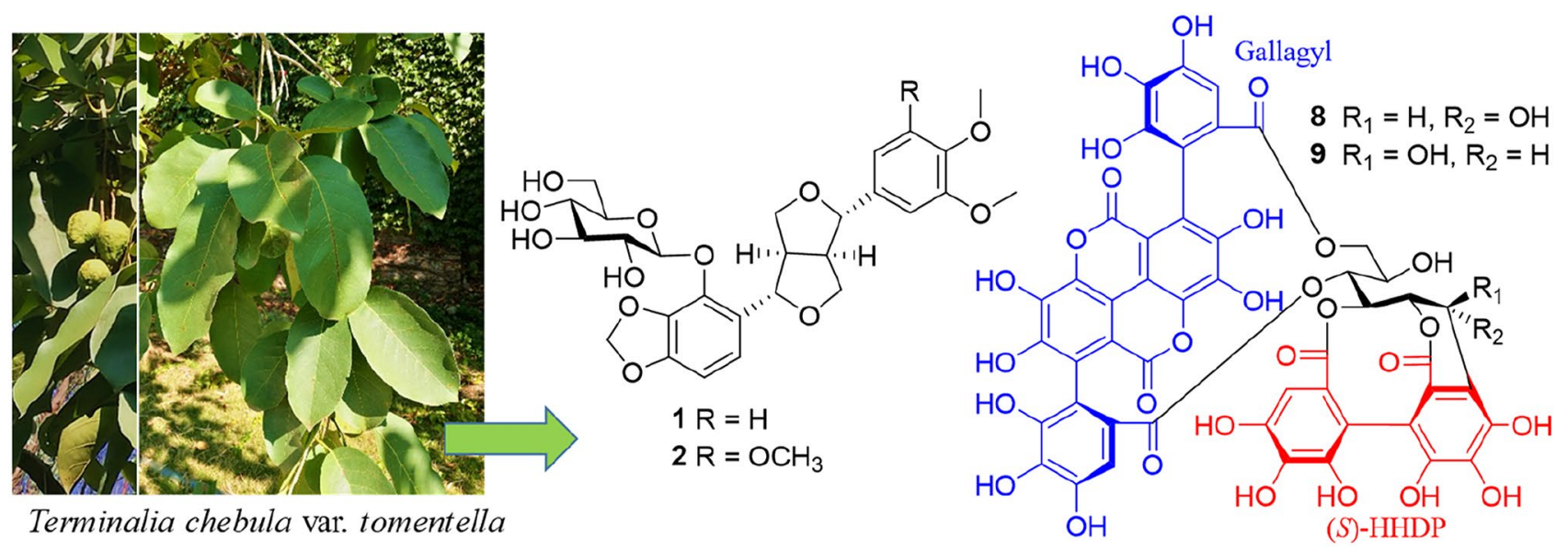

Keywords Terminalia chebula var. tomentella $\cdot$ Lignan glucosides $\cdot$ Hydrolyzable tannins $\cdot \alpha$-Glucosidase inhibitory activity $\cdot$ Calculated ECD

Ying-Jun Zhang

zhangyj@mail.kib.ac.cn

Extended author information available on the last page of the article 


\section{Introduction}

Terminalia Linn, the second largest genus in the family Combretaceae, is distributed globally in the tropical and subtropical areas. Among which, some species, such as $T$. catappa Linn, T. bellirica Roxb, and T. chebula Retz, are widely used medicinal plants. Particularly, T. chebula is a famous and commonly used medicinal plant in Ayurveda, Tibetan, and traditional Chinese medicinal systems. So far, 39 Terminalia species have been chemically and pharmacologically studied, from which 368 compounds, including terpenoids, hydrolyzable tannins, flavonoids, lignans, phenols and glycosides with a wide range of bioactivities, e.g., liver and kidney protection, antibacterial, anti-inflammatory, anticancer, immune regulation, anti-diabetes, and wound healing, were reported [1].

Terminalia chebula var. tomentella (Kurz) C. B. Clarke, a medium or large tree, is widely distributed in Himalaya, Madagascar and southern Asia [1]. The fruits have been recorded as Chebulae Fructus in the Chinese Pharmacopoeia, together with those of its original species, T. chebula, for the treatment of diarrhea, hemorrhoids, cough, and sore throat [2]. They have also been used traditionally in Tibetan medicines for the treatments of diabetic, tumor, and microbial infection. Our previous phytochemical investigations on the variety reported that the fruit contains rich hydrolyzable tannins, triterpenes, flavonoids, lignans and simple phenolics [3]. As a part of our efforts to search for unique structural constituents from the genus Terminalia, two new lignan glucosides termitomenins F and G (1-2), were isolated from the branches and leaves of $T$. chebula var. tomentella, along with five known lignan glucosides (3-7), six known hydrolyzable tannins (8-13) and eight simple phenolics (14-21). Their structures were determined by spectroscopic analyses and comparison of 1D/2D NMR, IR, UV, HRESIMS and calculated ECD analysis. Compounds 1-2 are new lignan glucosides with furofuran skeletons. All the isolates were evaluated for their $\alpha$-glucosidase inhibitory activities. Herein we describe the isolation, structural elucidation, and $\alpha$-glucosidase inhibitory activities of these compounds.

\section{Results, Discussion and Conclusion}

The detailed phytochemical investigation on the branches and leaves of $T$. chebula var. tomentella afforded two new lignan glucosides (1-2) (Fig. 1). In addition, 19 known compounds (3-21) were isolated and identified as five lignan glucosides, termitomenin D (3) [3], termitomenin E (4) $[3],(+)-\left(7 S, 8 S, 8^{\prime} S\right)-9-O$-[ $\beta$-D-glucopyranoyl] asarininone (5) [4], terminaloside Q (6) [5], and samsesquinoside
(7) [6], six hydrolyzable tannins, punicacortein C (8) [7], punicacortein D (9) [7], punicalagin (10) [8], 1,3,6-tri$O$-galloyl- $\beta$-D-glucopyranose (11) [9], 1,2,3,4,6-penta$O$-galloyl- $\beta$-D-glucopyranose (12) [9], and corilagin (13) [10], and six simple phenolics, shikimic acid (14) [11], (-)-5-O-galloylshikimic acid (15) [12], chebulic acid (16) [13], gallic acid (16) [14], 2,5-dihydroxybenzoic acid (18) [15], propyl gallate (19) [16], brevifolincarboxylic acid (20) [17], and glycerol-1-gallate (21) [18], respectively, on account of comparison of their NMR and HRESIMS data with those recorded in the literatures (Fig. 1). Compounds 8-9 were $C$-glycosidic hydrolyzable tannins with one hexahydroxydiphenoyl (HHDP) and one gallagyl group linked to an open-chain glucosyl $C-1 / O-2 / O-3$ and $O-4 / O-6$, rarely found to exist in plants. Compounds 1-2, 6-9, 13, and 18-21 were obtained from the titled plant for the first time, while 3-5, 10-12, and 14-17 were also found in the fruits.

Compound 1 was isolated as a yellowish oil. In the HRESIMS $^{-}$, a quasi-molecular ion peak at $\mathrm{m} / z$ 593.1885 $\left[\mathrm{M}+\mathrm{HCOO}^{-}\right.$(calcd for 593.1876), indicated a molecular formula of $\mathrm{C}_{27} \mathrm{H}_{32} \mathrm{O}_{12}$, corresponding to 12 unsaturation degrees. In the ${ }^{13} \mathrm{C}$ NMR and DEPT spectra of $\mathbf{1}$ (Table 1), 27 carbon signals including 12 aromatic carbons $\left(\delta_{\mathrm{C}}\right.$ 100-160) arising from two benzene rings, one methylenedioxy $\left(\delta_{\mathrm{C}} 102.7\right)$, four aliphatic methines $\left(\delta_{\mathrm{C}} 54.8,55.7\right)$ with two oxygen-bearing ones $\left(\delta_{\mathrm{C}} 83.6,87.4\right)$, two oxymethylenes $\left(\delta_{\mathrm{C}} 75.0,72.4\right)$, and two methoxys $\left(2 \mathrm{C}, \delta_{\mathrm{C}} 56.6\right)$ were observed, in addition to a glucosyl moiety $\left(\delta_{\mathrm{C}} 102.5\right.$, 78.7, 78.3, 75.6, 71.7, 62.8). The ${ }^{1} \mathrm{H}$ NMR spectrum showed the presence of one trisubstituted $\left[\delta_{\mathrm{H}} 6.98\left(1 \mathrm{H}, \mathrm{s}, \mathrm{H}-2^{\prime}\right)\right.$, $6.93(2 \mathrm{H}$, brs, H-5', H-6')] and one 1,2,3,4-tetrasubstituted $\left[\delta_{\mathrm{H}} 6.54,6.88\right.$ (each $\left.\left.1 \mathrm{H}, \mathrm{d}, J=8.1 \mathrm{~Hz}, \mathrm{H}-5, \mathrm{H}-6\right)\right]$ benzene rings. These ${ }^{1} \mathrm{H}$ and ${ }^{13} \mathrm{C}$ NMR features were closely related to those of termitomenin D (3), a furofuran lignan glucoside isolated from the fruits of the titled plant [3], except that one methylenedioxy group in $\mathbf{3}$ was changed to two methoxy groups $\left(2 \mathrm{C}, \delta_{\mathrm{C}} 56.6\right)$ in 1. Further HSQC and ${ }^{1} \mathrm{H}-{ }^{1} \mathrm{H}$ COSY experiments could assign completely all the proton signals and their corresponding carbons, together with the furofuran skeleton in $\mathbf{1}$. In the HMBC spectrum of $\mathbf{1}$, the correlations (Fig. 2) of H-7 $\left(\delta_{\mathrm{H}} 5.19\right)$ with C-1 $\left(\delta_{\mathrm{C}} 128.4\right) / \mathrm{C}-2\left(\delta_{\mathrm{C}} 138.8\right) /$ C-6 $\left(\delta_{\mathrm{C}} 119.7\right)$, and H-7' $\left(\delta_{\mathrm{H}} 4.65\right)$ with C-1' $\left(\delta_{\mathrm{C}} 135.4\right) / \mathrm{C}-2^{\prime}$ $\left(\delta_{\mathrm{C}} 111.3\right) / \delta_{\mathrm{C}} 120.1\left(\mathrm{C}-6^{\prime}\right)$ indicated the tetra- and tri- substituted benzene rings were located at C-7 and C-7', respectively. Moreover, the HMBC correlations of all the orthocoupled aromatic proton at $\delta_{\mathrm{H}} 6.88(\mathrm{~d}, J=8.1 \mathrm{~Hz}, \mathrm{H}-6), \mathrm{H}-7$ and the glucosyl anomeric proton $\left(\delta_{\mathrm{H}} 5.39\right)$ with $\mathrm{C}-2\left(\delta_{\mathrm{C}}\right.$ 138.8) demonstrated the glucosyl unit located at $\mathrm{C}-2$ of the tetra-substituted benzene ring, whose C-3 and C-4 linked with a methylenedioxy group, as deduced by the HMBC correlations of the methylenedioxy protons at $\delta_{\mathrm{H}} 5.96$ and 5.90 $\left(\mathrm{H}_{2}-10\right)$ with $\mathrm{C}-3\left(\delta_{\mathrm{C}} 137.1\right) / \mathrm{C}-4\left(\delta_{\mathrm{C}} 150.5\right)$, and both $\mathrm{H}_{2}-10$ and the ortho-coupled aromatic $\mathrm{H}-6\left(\delta_{\mathrm{H}} 6.88\right)$ with $\mathrm{C}-4$. 


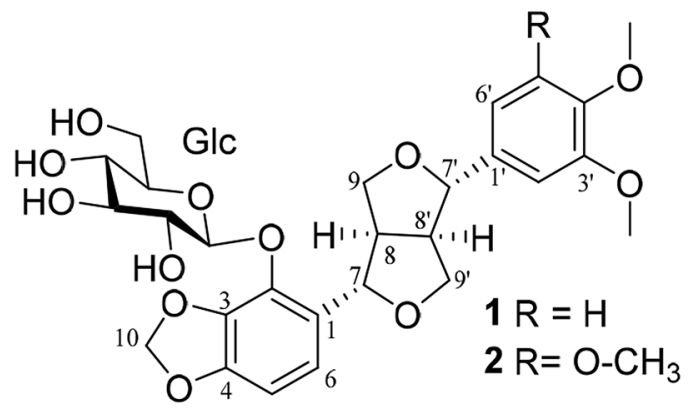

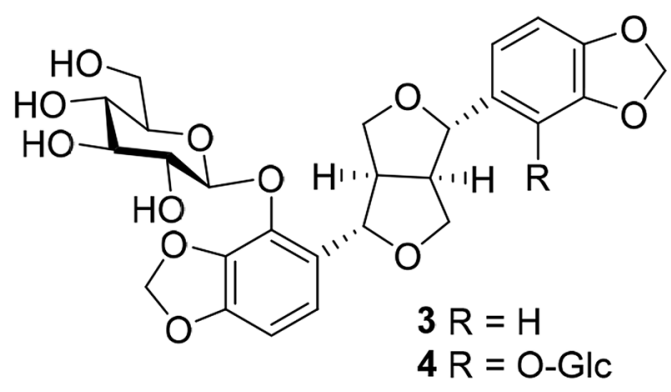<smiles>O=C(c1ccc2c(c1)OCO2)[C@H]1CO[C@@H](c2ccc3c(c2)OCO3)[C@@H]1COC(O)C(O)CO</smiles><smiles>COc1cc([C@H]2OC[C@@H](C(=O)c3ccc4c(c3)OCO4)[C@H]2COC2OCC(O)(CO)C(CO)(CO)O2)cc(OC)c1OC</smiles><smiles>COc1cc([C@H](O)[C@H](CO)Oc2c(OC)cc([C@@H]3OC[C@@H]4[C@H](c5ccc(OC6CCCCC6)c(OC)c5)OC[C@H]34)cc2OC)ccc1O</smiles>

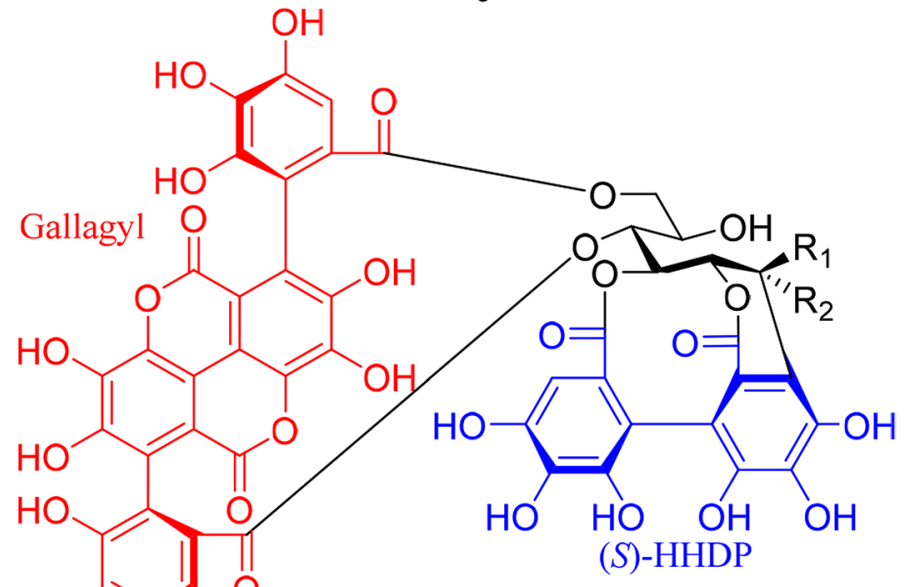

Galloyl $\mathrm{OH}$<smiles>CC(O)=C(C)O</smiles>
$8 \mathrm{R}_{1}=\mathrm{H}, \mathrm{R}_{2}=\mathrm{OH}$
$9 \mathrm{R}_{1}=\mathrm{OH}, \mathrm{R}_{2}=\mathrm{H}$

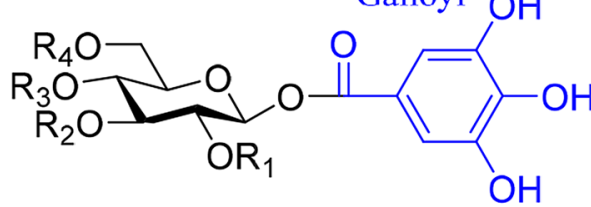

$11 \mathrm{R}_{1}=\mathrm{R}_{3}=\mathrm{H}, \mathrm{R}_{2}=\mathrm{R}_{4}=$ Galloyl

$12 R_{1}=R_{2}=R_{3}=R_{4}=$ Galloyl

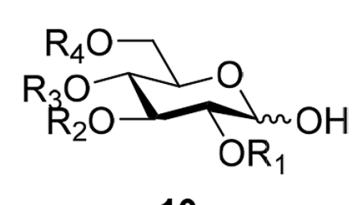

10

$13 R_{1}=R_{3}=H, R_{2}+R_{4}=(R)-H H D P$

$$
\mathrm{R}_{1}+\mathrm{R}_{2}=(S) \text {-HHDP, }
$$<smiles>[R9][C@H]1C=C(C(=O)O)C[C@H](O)[C@@H]1O</smiles><smiles>O=C(O)c1cc(O)ccc1O</smiles><smiles>O=C(O)CC(C(=O)O)C1c2c(cc(O)c(O)c2O)C(=O)OC1C(=O)O</smiles><smiles>[R]OC(=O)c1cc(O)c(O)c(O)c1</smiles><smiles>O=C1CC(C(=O)O)c2c1oc(=O)c1cc(O)c(O)c(O)c21</smiles><smiles>O=C(OCC(O)CO)c1cc(O)c(O)c(O)c1</smiles>

Fig. 1 Compounds 1-21 isolated from Terminalia chebula var. tomentella 
Table $1{ }^{1} \mathrm{H}(600 \mathrm{MHz})$ and ${ }^{13} \mathrm{C}(150 \mathrm{MHz})$ NMR data of $\mathbf{1}$ in $\mathrm{CD}_{3} \mathrm{OD}(\delta$ in ppm, $J$ in $\mathrm{Hz})$

\begin{tabular}{llllrl}
\hline No. & $\delta_{\mathrm{C}}$ & $\delta_{\mathrm{H}}$, mult. $(J)$ & No. & \multicolumn{1}{l}{$\delta_{\mathrm{C}}$} & $\delta_{\mathrm{H}}$, mult. $(J)$ \\
\hline 1 & 128.4 & & $5^{\prime}$ & 112.9 & $6.93 \mathrm{brs}$ \\
2 & 138.8 & $6^{\prime}$ & 120.1 & $6.93 \mathrm{brs}$ \\
3 & 137.1 & & $7^{\prime}$ & 87.4 & $4.65 \mathrm{~d}(6.2)$ \\
4 & 150.5 & & $8^{\prime}$ & 55.7 & $3.01 \mathrm{~m}$ \\
5 & 103.7 & $6.54 \mathrm{~d}(8.1)$ & $9^{\prime}$ & 72.4 & $4.18 \mathrm{dd}(9.1,6.2)$ \\
6 & 119.7 & $6.88 \mathrm{~d}(8.1)$ & & & $3.92 \mathrm{dd}(9.1,3.5)$ \\
7 & 83.6 & $5.19 \mathrm{~d}(4.3)$ & $3^{\prime}-\mathrm{OCH}_{3}$ & 56.6 & $3.84 \mathrm{~s}$ \\
8 & 54.8 & $3.22 \mathrm{~m}$ & $4^{\prime}-\mathrm{OCH}_{3}$ & 56.6 & $3.86 \mathrm{~s}$ \\
9 & 75.0 & $4.38 \mathrm{dd}(8.9,7.7)$ & $\mathrm{Glc}^{\prime \prime}$ & 102.5 & $5.39 \mathrm{~d}(7.6)$ \\
& & $4.03 \mathrm{dd}(8.9,5.1)$ & $2^{\prime \prime}$ & 75.6 & $3.43 \mathrm{~m}$ \\
10 & 102.7 & $5.96 \mathrm{~d}(1.2), 5.90$ & $3^{\prime \prime}$ & 78.3 & $3.35 \mathrm{~m}$ \\
& & $\mathrm{~d}(1.2)$ & & & \\
$1^{\prime}$ & 135.4 & & $4^{\prime \prime}$ & 71.7 & $3.34 \mathrm{~m}$ \\
$2^{\prime}$ & 111.3 & $6.98 \mathrm{~s}$ & $5^{\prime \prime}$ & 78.7 & $3.35 \mathrm{~m}$ \\
$3^{\prime}$ & 150.3 & & $6^{\prime \prime}$ & 62.8 & $3.85 \mathrm{~m}$, \\
$4^{\prime}$ & 150.8 & & & & $3.65 \mathrm{dd}(12.1,5.2)$ \\
\hline
\end{tabular}

Moreover, two additional methoxy protons at $\delta_{\mathrm{H}} 3.84$ and $3.86\left(3^{\prime}-\mathrm{OCH}_{3}, 4^{\prime}-\mathrm{OCH}_{3}\right)$ showed HMBC correlations with $\delta_{\mathrm{C}} 150.3\left(\mathrm{C}-3^{\prime}\right)$ and $\delta_{\mathrm{C}} 150.8\left(\mathrm{C}-4^{\prime}\right)$, respectively. Their locations at $\mathrm{C}-3^{\prime}$ and $\mathrm{C}-4^{\prime}$ were further confirmed by the ROESY correlations of $3^{\prime}-\mathrm{OCH}_{3}\left(\delta_{\mathrm{H}} 3.84\right)$ with H-2' $\left(\delta_{\mathrm{H}} 6.98\right)$, and $4^{\prime}-\mathrm{OCH}_{3}\left(\delta_{\mathrm{H}} 3.86\right)$ with H-5' $\left(\delta_{\mathrm{H}} 6.93\right)$. Accordingly, the planar structure of 1 was constructed as shown in Fig. 1. The ROESY correlation of H- $8\left(\delta_{\mathrm{H}} 3.22\right)$ with $\mathrm{H}-6\left(\delta_{\mathrm{H}} 6.88\right) / \mathrm{H}-$ $8^{\prime}\left(\delta_{\mathrm{H}} 3.01\right)$, and $\mathrm{H}-8^{\prime}$ with $\mathrm{H}-2^{\prime}\left(\delta_{\mathrm{H}} 6.98\right)$ indicated that the cis-8, $8^{\prime}$-fused conformation in $\mathbf{1}$ and both benzene rings at C-7 and C-7' were at the same side to H- 8 and $\mathrm{H}-8^{\prime}$, that is, $\mathrm{H}-7\left(\delta_{\mathrm{H}} 5.19\right)$ and $\mathrm{H}-8\left(\delta_{\mathrm{H}} 3.22\right), \mathrm{H}-7^{\prime}\left(\delta_{\mathrm{H}} 4.65\right)$ and $\mathrm{H}-8^{\prime}\left(\delta_{\mathrm{H}}\right.$ 3.01) were at the opposite orientations, respectively. This was also supported by the ROESY correlations of H-7 $\left(\delta_{\mathrm{H}}\right.$ 5.19) with $\mathrm{H}-9 \beta\left(\delta_{\mathrm{H}} 4.03\right), \mathrm{H}-8\left(\delta_{\mathrm{H}} 3.22\right)$ with $\mathrm{H}-9 \alpha\left(\delta_{\mathrm{H}}\right.$ $4.38), \mathrm{H}-7^{\prime}\left(\delta_{\mathrm{H}} 4.65\right)$ with $\mathrm{H}-9^{\prime} \beta\left(\delta_{\mathrm{H}} 3.92\right)$, and $\mathrm{H}-8^{\prime}\left(\delta_{\mathrm{H}}\right.$ $3.01)$ with $\mathrm{H}-9^{\prime} \alpha\left(\delta_{\mathrm{H}} 4.18\right)$. Finally, the ECD calculation of $\left(7 S, 8 R, 7^{\prime} S, 8^{\prime} R\right)-1$ matched well with the experimental ECD curve of $\mathbf{1}$, established the absolute configuration of $\mathbf{1}$ as $7 S, 8 R, 7^{\prime} S, 8^{\prime} R$ (Fig. 3). According to the above mentioned

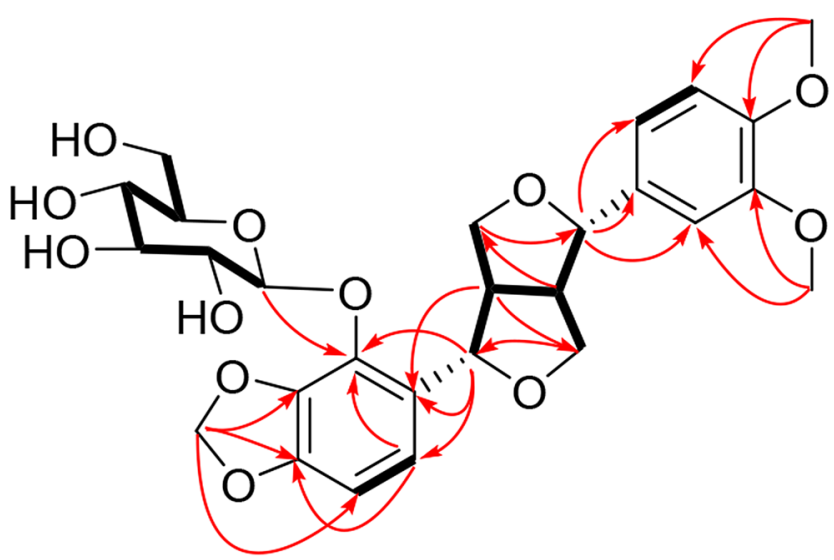<smiles>C[AsH3]O[SiH3]</smiles>

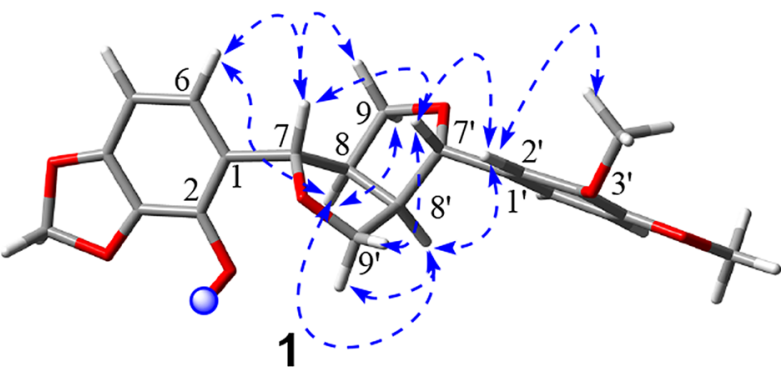

1

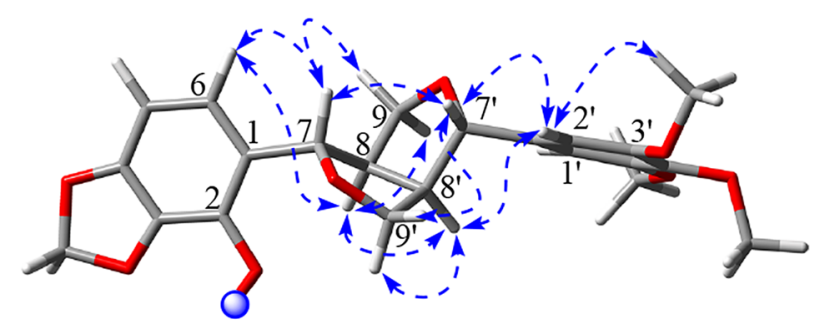

2

Fig. 2 Key ${ }^{1} \mathrm{H}-{ }^{1} \mathrm{H}$ COSY, HMBC and ROESY correlations of compounds $\mathbf{1}$ and $\mathbf{2}$ 

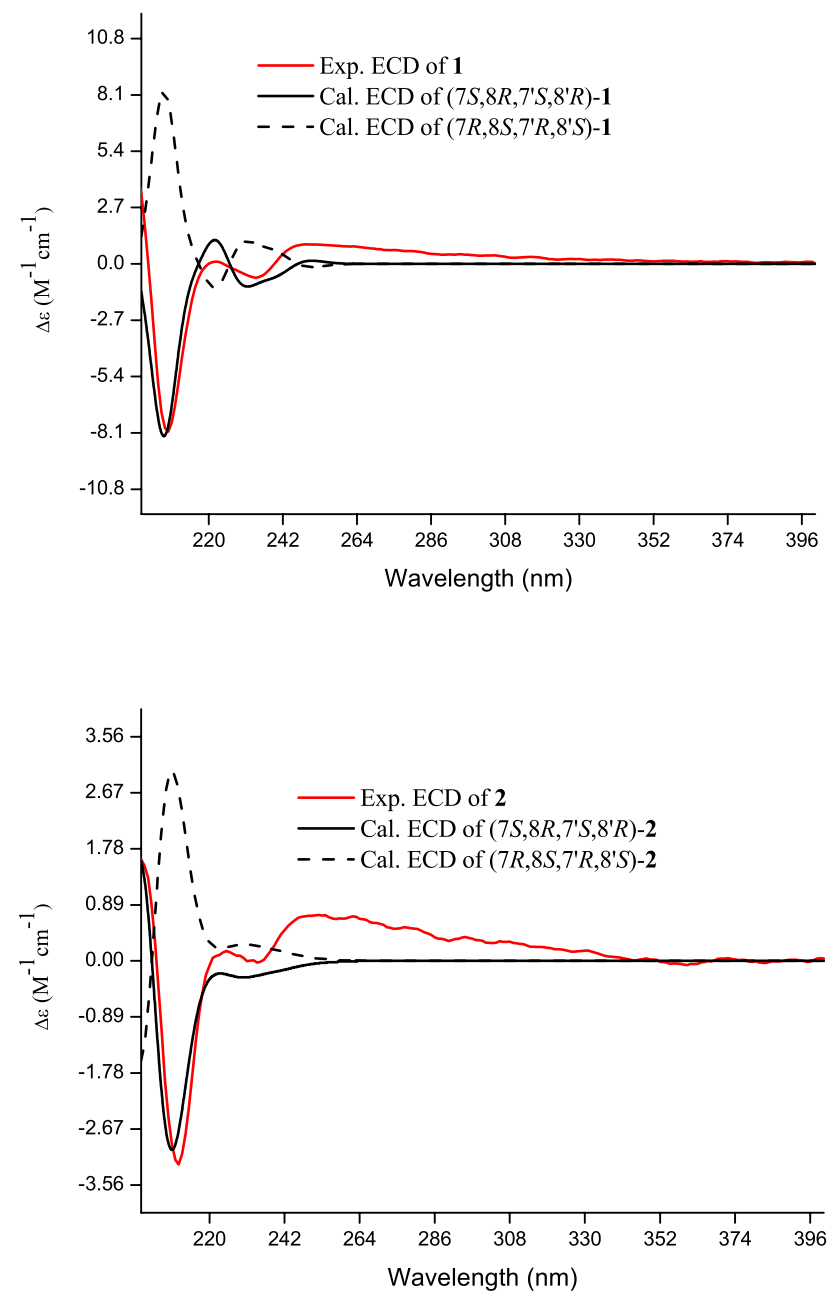

Fig. 3 Calculated and experimental ECD spectra of compounds 1 and 2 evidence, the structure of compound $\mathbf{1}$ was determined as shown in Fig. 1 and named as termitomenin F.

Compound 2 was isolated as a yellow oil. In the HRESIMS $^{-}$, a quasi-molecular ion peak appeared at $\mathrm{m} / \mathrm{z}$ $613.1700[\mathrm{M}+\mathrm{Cl}]^{-}\left(\right.$calcd for $\left.613.1693[\mathrm{M}+\mathrm{Cl}]^{-}\right)$, indicating a molecular formula of $\mathrm{C}_{28} \mathrm{H}_{34} \mathrm{O}_{13}$, corresponding to 12 unsaturation degrees. In the ${ }^{13} \mathrm{C}$ NMR and DEPT spectra of 2 (Table 2) displayed the presence of 28 carbon signals including 12 aromatic carbons $\left(\delta_{\mathrm{C}} 100-160 \mathrm{ppm}\right)$ arising from two benzene rings, one methylenedioxy $\left(\delta_{\mathrm{C}}\right.$ 102.7), four aliphatic methines $\left(\delta_{\mathrm{C}} 54.8,56.1\right)$ with two oxygen-bearing ones $\left(\delta_{\mathrm{C}} 83.6,87.5\right)$, two oxymethylenes $\left(\delta_{\mathrm{C}} 75.2,72.4\right)$, and three methoxys $\left[\delta_{\mathrm{C}} 56.8(\times 2), 61.2\right]$, and six carbon signals $\left(\delta_{\mathrm{C}} 102.5,78.7,78.3,75.6,71.7\right.$, 62.7) from a glucosyl moiety. The ${ }^{1} \mathrm{H}$ NMR spectrum of 2 showed characteristic signals of two ortho-coupled aromatic protons at $\delta_{\mathrm{H}} 6.53,6.88$ (each $1 \mathrm{H}, \mathrm{d}, J=8.1 \mathrm{~Hz}, \mathrm{H}-5, \mathrm{H}-6$ ), one two-proton singlet at $\delta_{\mathrm{H}} 6.68\left(2 \mathrm{H}, \mathrm{s}, \mathrm{H}-2^{\prime}, \mathrm{H}-6^{\prime}\right)$, one anomeric proton at $\delta_{\mathrm{H}} 5.39(1 \mathrm{H}, J=7.5 \mathrm{~Hz}, \mathrm{H}-1 ")$, and a set of signals from $\delta_{\mathrm{H}} 2.99$ to 5.18 due to a furofuran skeleton, a glucosyl and a methylenedioxy moieties. The ${ }^{13} \mathrm{C}$ and ${ }^{1} \mathrm{H}$ NMR features of $\mathbf{2}$ were quite similar to those of $\mathbf{1}$, except that $\mathbf{2}$ had one more methoxy group $\left(\delta_{\mathrm{C}} 61.2\right)$ than $\mathbf{1}$. Compound $\mathbf{2}$ was also a furofuran lignan glucoside. Instead of the 1,3,4-trisubsituted benzene ring in $\mathbf{1}$, a symmetric 1,3,4,5-tetrasubstituted benzene ring appeared in $\mathbf{2}$. These were further confirmed by the 2D NMR experiment. In the HMBC spectrum of $2, \delta_{\mathrm{H}} 3.84\left(6 \mathrm{H}, \mathrm{s}, 3^{\prime}-\mathrm{OCH}_{3}, 5^{\prime}-\mathrm{OCH}_{3}\right)$ and $3.74\left(3 \mathrm{H}, \mathrm{s}, 4^{\prime}-\mathrm{OCH}_{3}\right)$ showed respectively correlations with $\delta_{\mathrm{C}} 154.8\left(\mathrm{C}-3^{\prime}, \mathrm{C}-5^{\prime}\right)$ and $138.6\left(\mathrm{C}-4^{\prime}\right)$, indicating the three methoxy groups were at C-3', C-4' and C-5' (Fig. 2). Other HMBC correlations also supported the planar structure of $\mathbf{2}$ as shown in Fig. 1. Moreover, the ROESY experiment showed that the relative configuration of $\mathbf{2}$ was the
Table $2{ }^{1} \mathrm{H}(600 \mathrm{MHz})$ and ${ }^{13} \mathrm{C}$ $(150 \mathrm{MHz})$ NMR data of $\mathbf{2}$ in $\mathrm{CD}_{3} \mathrm{OD}(\delta$ in ppm, $J$ in $\mathrm{Hz})$

\begin{tabular}{llllrl}
\hline No. & $\delta_{\mathrm{C}}$ & $\delta_{\mathrm{H}}$, mult. $(J)$ & No. & \multicolumn{1}{c}{$\delta_{\mathrm{C}}$} & $\delta_{\mathrm{H}}$, mult. $(J)$ \\
\hline 1 & 128.4 & & $4^{\prime}$ & 138.6 & \\
2 & 138.8 & & $7^{\prime}$ & 87.5 & $4.66 \mathrm{~d}(6.1)$ \\
3 & 137.1 & & $8^{\prime}$ & 56.1 & $2.99 \mathrm{dtd}(9.7,6.1,3.5)$ \\
4 & 150.5 & & $9^{\prime}$ & 72.4 & $4.19 \mathrm{dd}(9.2,6.1)$ \\
5 & 103.7 & $6.53 \mathrm{~d}(8.1)$ & & & $3.96 \mathrm{dd}(9.2,3.5)$ \\
6 & 119.7 & $6.88 \mathrm{~d}(8.1)$ & $3^{\prime}, 5^{\prime}-\mathrm{OCH}_{3}$ & 56.8 & $3.84 \mathrm{~s}$ \\
7 & 83.6 & $5.18 \mathrm{~d}(4.3)$ & $4^{\prime}-\mathrm{OCH}_{3}$ & 61.2 & $3.74 \mathrm{~s}$ \\
8 & 54.8 & $3.20 \mathrm{~m}$ & $\mathrm{Glc}^{\prime \prime} 1^{\prime \prime}$ & 102.5 & $5.39 \mathrm{~d}(7.5)$ \\
9 & 75.2 & $4.39 \mathrm{dd}(9.0,7.4)$ & $2^{\prime \prime}$ & 75.6 & $3.41 \mathrm{~m}$ \\
& & $4.05 \mathrm{dd}(9.0,5.1)$ & $3^{\prime \prime}$ & 78.3 & $3.34 \mathrm{~m}$ \\
10 & 102.7 & $5.95 \mathrm{~d}(1.0), 5.89 \mathrm{~d}(1.0)$ & $4^{\prime \prime}$ & 71.7 & $3.45 \mathrm{~m}$ \\
$1^{\prime}$ & 139.0 & & $5^{\prime \prime}$ & 78.7 & $3.35 \mathrm{~m}$ \\
$2^{\prime}, 6^{\prime}$ & 104.4 & $6.68 \mathrm{~s}$ & $6^{\prime \prime}$ & 62.7 & $3.82 \mathrm{~m}$ \\
$3^{\prime}, 5^{\prime}$ & 154.8 & & & & $3.64 \mathrm{dd}(11.9,5.1)$ \\
\hline
\end{tabular}


Table $3 \alpha$-Glucosidase inhibitory activity of compounds $\mathbf{8}-\mathbf{1 3}$ from the branches and leaves of Terminalia chebula var. tomentella ${ }^{a}$

\begin{tabular}{ll}
\hline Sample & $\mathrm{IC}_{50}(\mu \mathrm{M})^{b}$ \\
\hline Quercetin $^{c}$ & $9.38 \pm 0.33$ \\
$\mathbf{8}$ & $1.96 \pm 0.01$ \\
$\mathbf{9}$ & $1.72 \pm 0.07$ \\
$\mathbf{1 0}$ & $0.27 \pm 0.01$ \\
$\mathbf{1 1}$ & $2.28 \pm 0.07$ \\
$\mathbf{1 2}$ & $0.10 \pm 0.01$ \\
$\mathbf{1 3}$ & $3.12 \pm 0.23$ \\
\hline
\end{tabular}

${ }^{a}$ Values represent means $\pm \mathrm{SD}$ $(\mathrm{n}=3) .{ }^{\mathrm{b}} \mathrm{IC}_{50}=$ one-half maximal inhibitory concentration to $\alpha$-glucosidase. ${ }^{c}$ Positive control

same as that of 1 (Fig. 2). In which, the ROESY correlations of H-8 $\left(\delta_{\mathrm{H}} 3.20\right)$ with H-6 $\left(\delta_{\mathrm{H}} 6.88\right) / \mathrm{H}-8^{\prime}\left(\delta_{\mathrm{H}} 2.99\right)$, and $\mathrm{H}-8^{\prime}$ with $\mathrm{H}-2^{\prime}\left(\delta_{\mathrm{H}} 6.68\right) / \mathrm{H}-6^{\prime}$ indicated that $\mathrm{H}-7$ and $\mathrm{H}-8$, and $\mathrm{H}-7^{\prime}$ and $\mathrm{H}-\mathrm{8}^{\prime}$ were at the opposite orientations, respectively. This was confirmed by the ROESY correlations of $\mathrm{H}-7$ with $\mathrm{H}-9 \beta, \mathrm{H}-8$ with $\mathrm{H}-9 \alpha, \mathrm{H}-7^{\prime}$ with $\mathrm{H}-9^{\prime} \beta$, and $\mathrm{H}-8^{\prime}$ with $\mathrm{H}_{-} 9^{\prime} \alpha$. Eventually, the ECD calculation of $\left(7 S, 8 R, 7^{\prime} S, 8^{\prime} R\right)-2$ matched well with the experimental ECD curve of $\mathbf{2}$, revealed the absolute configuration of $\mathbf{2}$ as $7 S, 8 R, 7^{\prime} S, 8^{\prime} R$ (Fig. 3). According to the aforementioned evidence, the structure of compound $\mathbf{2}$ was determined as shown in Fig. 1 and named as termitomenin G.

Compounds 1-21 were evaluated for their hypoglycemic activity with quercetin as positive controls [19]. As shown in Table 3, only the hydrolyzable tannins 8-13 showed $\alpha$-glucosidase inhibitory activities with the $\mathrm{IC}_{50}$ values from 0.10 to $3.12 \mu \mathrm{M}$, stronger than the positive control, quercetin $\left(\mathrm{IC}_{50}=9.38 \pm 0.33 \mu \mathrm{M}\right)$, while the other compounds did not show obvious inhibitory activity at a concentration of $50 \mu \mathrm{M}$. Among them, compound $\mathbf{1 2}$ with five galloyl group in molecular showed the strongest effect on $\alpha$-glucosidase, followed with $\mathbf{1 0}>\mathbf{9}>\mathbf{8}>\mathbf{1 1}>\mathbf{1 3}$ by the order of activity strength. When the open-chain glucosyl moiety was fixed by a $C$-glycosidic bond with a HHDP group (8 and 9), it displayed less activity than that one (10) with a free glucosyl anomeric center. Moreover, compound 11 with nine phenol $\mathrm{OHs}$ arising from three galloyl groups showed a little bit stronger activity than 13 with the same nine phenol OHs from one galloyl and one HHDP groups. The results suggested that galloyl and HHDP groups may play a vital role for the $\alpha$-glucosidase inhibitory activity of these compounds (8-13), much stronger than those lignan glucosides and phenolic compounds.

\section{Experimental Section}

\subsection{General Experimental Procedures}

One- and two-dimensional NMR spectra were determined on methanol- $d_{4}$ or $\mathrm{D}_{2} \mathrm{O}$ with Bruker Ascend 600 and AV-800 spectrometers. Coupling constants were expressed in hertz $(\mathrm{Hz})$, and chemical shifts were recorded in a $\delta$ (parts per million, ppm) scale with TMS (Bruker, Zurich, Switzerland) as an internal standard. ESI mass spectra were measured on a VG Auto Spec300 spectrometer. High-resolution electrospray ionization mass (HRESIMS) spectra were measured on an API QSTAR Pular-1 spectrometer. Optical rotations were taken on JASCO P-1020 digital polarimeter. IR spectra were recorded on Bio-Rad FTS 135 series spectrometer with $\mathrm{KBr}$ pellets. UV spectra were given on and UV-2410PC Shimadzu spectrometer. Column chromatography (CC) was performed on 25-100 $\mu \mathrm{m}$ Sephadex LH-20 (Pharmacia Fine Chemical Co., Ltd., Uppsala, Sweden), 75-100 $\mu \mathrm{m}$ MCIgel CHP20P (Mitsubishi Chemical Co. Ltd., Tokyo, Japan), and 100-150 mesh silica gel (Qingdao Marine Chemical, Inc., Qingdao, China). Thin-layer chromatography (TLC) was performed on precoated $0.20-0.25 \mathrm{~mm}$ thick silica gel GF254 plates (Qingdao Haiyang Chemical Co., Qingdao, China), Agilent series 1260 (Agilent Technologies) were used for semi-preparative HPLC with an Agilent ZORBAX SB-C18 column $(5 \mu \mathrm{m}, 250 \mathrm{~mm} \times 9.4 \mathrm{~mm})$. Acetonitrile (chromatographic grade) were purchased from Merck (Darmstadt, FR, Germany). Water was purified in a Milli-Q apparatus (Millipore). 4-Nitrophenyl- $\alpha$-D-glucopyranoside (PNPG) was procured from America Sigma Chemical Co. $\alpha$-Glucosidase and quercetin were purchased from Sigma Chemical (Merck KGaA, Darmstadt, Germany). Potassium phosphate buffer solution (PPBS) was purchased from Shanghai Xilong Biochemical Technology Co. Ltd. 96-well plates was obtained from Qingdao Haiyang Chemical Co., Ltd.

\subsection{Plant Material}

The branches and leaves of Terminalia chebula var. tomentella (Kurz) C. B. Clarke (Combretaceae), identified by Dr. En-De Liu from Kunming Institute of Botany, Chinese Academy of Sciences, were collected in Lincang County, Yunnan Province, P. R. China, on November 2017. A standard sample (KIB-1-Z-20171102) has been deposited in the State Key Laboratory of Phytochemistry and Plant Resource in West China of Kunming Institute of Botany. 


\subsection{Extraction and Isolation}

The air-dried branches and leaves of T. chebula var. tomentella $(10 \mathrm{~kg})$ were crushed and extracted by $60 \%$ aqueous acetone solution at room temperature. After removal of organic solvent by rotary evaporator at $45{ }^{\circ} \mathrm{C}$ under reduced pressure, the crude aqueous extract $(3 \mathrm{~L})$ was applied to a Diaion HP-20 column chromatography (water-methanol 1:0-0:1) to obtain three fractions, Fr. I-III. Fr. I (355.9 g) was applied to repeated CC over Sephadex LH-20, MCI-gel CHP20P, Toyopearl HW-40F, and MCI-gel CHP20P, eluting with water-methanol (1:0-0:1), to furnish compounds $\mathbf{7}(5 \mathrm{mg}), \mathbf{8}(3 \mathrm{mg}), \boldsymbol{9}(3 \mathrm{mg}), \mathbf{1 0}(55 \mathrm{mg})$, and $\mathbf{1 1}(15 \mathrm{mg})$. Fr. II (163.9 g) was applied to repeated CC over Sephadex LH-20, MCI-gel CHP20P, Toyopearl HW-40F, and Rp18, eluting with water-methanol (1:0-0:1), to obtain compounds $\mathbf{3}$ (5 mg), 4 (2 mg), 5 (2 mg), and $\mathbf{1 4}$ (3 mg). Fr. III (993.4 g) was separately chromatographed over Sephadex LH-20, MCI-gel CHP20P, Toyopearl HW-40F water-methanol $(1: 0-3: 7)$, and silica gel $\mathrm{CC}$ eluting with $\mathrm{CHCl}_{3} / \mathrm{MeOH}$ 15:1-1:1, to yield compounds $1(5 \mathrm{mg}), \mathbf{2}(5 \mathrm{mg}), \mathbf{6}(20 \mathrm{mg})$, 12 (13 mg), 13 (10 mg), 15 (16 mg), 16 (4 mg), 17 (3 mg), 18 (4 mg), 19 (5 mg), 20 (0.9 mg), and 21 (6 mg).

\subsubsection{Termitomenin F (1)}

Colorless oil, $[\alpha]_{\mathrm{D}}^{22}-13.2(c 0.09, \mathrm{MeOH})$. UV (MeOH) $\lambda_{\max }(\log \varepsilon) 205(3.65) \mathrm{nm}$. IR (KBr) $\nu_{\max } 3399,2923,2875$, $1467,1260 \mathrm{~cm}^{-1}$. ${ }^{1} \mathrm{H}(600 \mathrm{MHz})$ and ${ }^{13} \mathrm{C}(150 \mathrm{MHz}) \mathrm{NMR}$ (in methanol- $d_{4}$ ) data, see Table 1. HRESIMS (negativeion mode) $\mathrm{m} / \mathrm{z} 593.1885[\mathrm{M}+45(\mathrm{COOH})]^{-}$(calcd for $\mathrm{C}_{28} \mathrm{H}_{33} \mathrm{O}_{14}$, 593.1876).

\subsubsection{Termitomenin G (2):}

Colorless oil, $[\alpha]_{\mathrm{D}}^{22}-4.1($ c 0.075, MeOH). UV (MeOH) $\lambda_{\max }(\log \varepsilon) 205(3.71) \mathrm{nm}$. IR $(\mathrm{KBr}) \nu_{\max } 3409,2925,1630$, $1465 \mathrm{~cm}^{-1}$. ${ }^{1} \mathrm{H}(600 \mathrm{MHz})$ and ${ }^{13} \mathrm{C}(150 \mathrm{MHz}) \mathrm{NMR}$ (in methanol- $d_{4}$ ) data, see Table 2. HRESIMS (negative-ion mode) $\mathrm{m} / \mathrm{z} 613.1700[\mathrm{M}+\mathrm{Cl}]^{-}$(calcd for $\mathrm{C}_{28} \mathrm{H}_{34} \mathrm{O}_{13} \mathrm{Cl}$, 613.1693).

\subsection{ECD Computational Details}

Conformational analyzes were conducted by random searching in the Sybyl Software X 2.0 using the MMFF-94S force field with an energy shortoff of $2.0 \mathrm{kcal} \mathrm{mol}^{-1}$. The results indicated six lowest energy conformers for compounds $\mathbf{1}$ and 2. Then, the conformers were re-optimized using DFT at the PBE0-D3(BJ)/def2-SVP level in Methanol using the polarizable conductor calculation model by the ORCA-4.2.1 program [20]. The energies, rotational strengths (velocity), and oscillator strengths of the first 60 electronic excitations were calculated using the TDDFT methodology at the PBE0/def2-TZVP level in Methanol. The electronic circular dichroism spectra were simulated by the overlapping Gaussian function (half the bandwidth at 1/e peak height, $\sigma=0.30$ for all) [21]. Eventually, the electronic circular dichroism spectra of compounds $\mathbf{1}$ and $\mathbf{2}$ were gained by weighing the Boltzmann distribution ratio of each geometric conformation.

\section{5 a-Glucosidase Inhibitory Activity}

The $\alpha$-glucosidase inhibitor screening assay was conducted as reported previously and slightly modified [22]. Quercetin was used as positive control. 4-Nitrophenol- $\alpha$-Dglucopyranoside (PNPG) was used as an enzyme inhibitor screening model. $\alpha$-glucosidase solution $\left(0.025 \mathrm{U} \cdot \mathrm{mL}^{-1}\right)$, PNPG (0.1 M), phosphate buffer (pH 6.8) and test samples $(50 \mu \mathrm{M})$ were incubated in 96 -well plates at $37{ }^{\circ} \mathrm{C}$ for $1 \mathrm{~h}$. A microplate reader was recorded by the absorbance at $405 \mathrm{~nm}$. No enzyme as the blank readings were subtracted from each well and compared to the control. In this assay, all reactions were performed in triplicate. The $\alpha$-glucosidase inhibitory activity was presented as inhibition ratio. The formula to calculate the inhibition rate is as follows: inhibition rate $(\%)=\left(1-\mathrm{OD}_{\text {experimental }} 405 \mathrm{~nm} / \mathrm{OD}_{\text {blank }} 405 \mathrm{~nm}\right) \times 100 \%$, and $\mathrm{IC}_{50}$ values were calculated according to the Reed and Muench method [23].

\section{Conclusion}

In conclusion, 21 phenolic compounds (1-21) including seven lignan glucosides (1-7), six hydrolyzable tannins (8-13) and eight simple phenolics (14-21) were isolated and determined from the branches and leaves of T. chebula var. tomentella. Compounds $\mathbf{1}$ and $\mathbf{2}$ were two new lignan glucosides with a furofuran skeleton, while $\mathbf{8}$ and $\mathbf{9}$ were $C$-glycosidic hydrolyzable tannins with one HHDP and one gallagyl groups linked to an open-chain glucosyl $C-1 / O$ $2 / O-3$ and $O-4 / O-6$, respectively, rarely found to exist in plants. Compounds 1-2, 6-9, 13, and 18-21 were obtained from the titled plant for the first time, while 3-5, 10-12, and 14-17 were also find in the fruits. The hydrolyzable tannins 8-13 exhibited strong $\alpha$-glucosidase inhibitory activities.

Supplementary Information The online version contains supplementary material available at https://doi.org/10.1007/s13659-021-00314-z.

Acknowledgements This research was supported by the National Natural Science Foundation of China (82074124) and the Key Project of Basic Research Plan of Yunnan Province, China (202001AS070017). The authors are grateful to the staffs of the analytical and bioactivity screening groups at the State Key Laboratory of Phytochemistry and Plant Resources in West China, Kunming Institute of Botany, Chinese Academy of Sciences, for measuring the spectroscopic data and $\alpha$-glucosidase inhibitory activity. 


\section{Declaration}

Conflict of interest The authors declare no competing financial interest.

Open Access This article is licensed under a Creative Commons Attribution 4.0 International License, which permits use, sharing, adaptation, distribution and reproduction in any medium or format, as long as you give appropriate credit to the original author(s) and the source, provide a link to the Creative Commons licence, and indicate if changes were made. The images or other third party material in this article are included in the article's Creative Commons licence, unless indicated otherwise in a credit line to the material. If material is not included in the article's Creative Commons licence and your intended use is not permitted by statutory regulation or exceeds the permitted use, you will need to obtain permission directly from the copyright holder. To view a copy of this licence, visit http://creativecommons.org/licenses/by/4.0/.

\section{References}

1. X.R. Zhang, J.S. Kaunda, H.T. Zhu, D. Wang, C.R. Yang, Y.J. Zhang, Nat. Prod. Bioprospect. 9, 357-392 (2019)

2. Chinese Pharmacopoeia Commission, Chinese pharmacopoeia, Book 1, p 187. China Medical Science Press: Beijing (2015)

3. X.R. Zhang, H.T. Zhu, D. Wang, Z. Yang, C.R. Yang, Y.J. Zhang, Fitoterapia 143, 1-30 (2020)

4. Z. Lei, Y. Zou, J. Xu, J. Zhang, X. Ye, W. Zhang, P. Lin, China Med. 40, 3214-3219 (2015)

5. M.A. Muhit, K. Umehara, K. Yasumoto, H. Noguchi, J. Nat. Prod. 79, 1298-1307 (2016)

6. H.H. Xiao, Y. Dai, M.S. Wong, X.S. Yao, Fitoterapia 94, 29-35 (2014)
7. H. Ito, P. Li, M. Koreishi, A. Nagatomo, N. Nishida, T. Yoshida, Food Chem. 152, 323-330 (2014)

8. T. Tanaka, G. Nonaka, I. Nishioka, Chem. Pharm. Bull. 34, 656663 (1986)

9. D. Söhretoglu, M.K. Sakar, S.A. Sabuncuoglu, H. Özgünes, O. Sterner, Rec. Nat. Prod. 5, 22 (2011)

10. E.Y.A. Salih, M. Kanninen, M. Sipi, O. Luukkanen, R. Hiltunen, H. Vuorela, R. Julkunen-Tiitto, P. Fyhrquist, S. Afr, J. Bot. 108, 370-386 (2017)

11. M. Liu, S. Yang, L. Jin, D. Hu, Z. Wu, S. Yang, Molecules 17, 6156-6169 (2012)

12. X.K. Zheng, Y.F. Bi, W.S. Feng, S.P. Shi, G. Wan, J.Z. Niu, Acta Pharm. Sin. 39, 266-268 (2004)

13. H.S. Lee, S.H. Jung, B.S. Yun, K.W. Lee, Arch. Toxicol. 81, 211-218 (2007)

14. W. Guo, J. Yu, D. Zhu, X. Chen, W. Hou, Chem. Nat. Compd. 56, 777-779 (2020)

15. H.Y. Guo, G.K. Wang, J.K. Liu, G. Wang, Chin. Tra. Pat. Med. 40, 129-133 (2018)

16. B. Li, J. Gao, L. Gong, P. Liu, S. Li, J. Chin. Med. Mater. 38, 1209-1211 (2015)

17. L. Wu, J. Wu, S.P. Chen, Z.J. Li, J. Zhang, E. Yuan, G.Q. Ma, L. Jin, J.W. Hu, Chem. Nat. Compd. 55, 324-326 (2019)

18. G. Nonaka, I. Nishioka, Chem. Pharm. Bull. 31, 1652-1658 (1983)

19. L. Zhang, Z.C. Tu, T. Yuan, H. Wang, X. Xie, Z.F. Fu, Food Chem. 208, 61-67 (2016)

20. F. Neese, WIREs Computational Molecular. Science 2, 73-78 (2012)

21. P.J. Stephens, N. Harada, Chirality 22, 229-233 (2010)

22. E. Apostolidis, Y.I. Kwon, K. Shetty, Innov. Food Sci. Emerg. 8, 46-54 (2007)

23. P. Haggett, K.A. Gunawardena, Prof. Geogr. 16, 6-9 (1964)

\section{Authors and Affiliations}

\section{Jun Yin ${ }^{1,2} \cdot$ Hong-Tao Zhu ${ }^{1} \cdot$ Man Zhang ${ }^{1} \cdot$ Dong Wang ${ }^{1} \cdot$ Chong-Ren Yang ${ }^{1} \cdot$ Ying-Jun Zhang ${ }^{1,3}$ (B)}

1 State Key Laboratory of Phytochemistry and Plant Resources in West China, Kunming Institute of Botany, Chinese Academy of Sciences, Kunming 650201, People's Republic of China

2 University of Chinese Academy of Sciences, Beijing 100049 , People's Republic of China
3 Yunnan Key Laboratory of Natural Medicinal Chemistry, Kunming Institute of Botany, Chinese Academy of Sciences, Kunming 650201, People's Republic of China 